\title{
Abiotic factors modulate interspecies competition mediated by the type VI secretion system effectors in Vibrio cholerae
}

Running title: Abiotic factors dictate effector effectiveness

Ming-Xuan Tang ${ }^{1}$, Tong-Tong Pei ${ }^{1}$, Zeng-Hang Wang ${ }^{1}$, Han Luo ${ }^{1}$, Xing-Yu Wang ${ }^{1}$, Tao G. Dong ${ }^{1,2^{*}}$

\section{Affiliations:}

${ }^{1}$ State Key Laboratory of Microbial Metabolism, Joint International Research Laboratory of Metabolic \& Developmental Sciences, School of Life Sciences and Biotechnology, Shanghai Jiao Tong University, Shanghai, 200240, China

${ }^{2}$ Department of Ecosystem and Public Health, University of Calgary, 3330 Hospital Dr. NW, Calgary, AB, T2N4Z6, Canada.

*Correspondence to tdong@ucalgary.ca

Keywords: protein secretion, interspecies interaction, effector, cation, adaptation

Subject Categories: Microbe-microbe and microbe-host interactions 


\section{Abstract}

Vibrio cholerae, the etiological pathogen of cholera, relies on its type VI secretion system (T6SS) as an

3 effective weapon to survive in highly competitive communities. The anti-bacterial and anti-eukaryotic functions

4 of T6SS depend on its secreted effectors that target multiple essential cellular processes. However, the mechanisms

5 that account for effector diversity and different effectiveness during interspecies competition remain elusive. Here,

6 we report that environmental cations and temperature play a key role in dictating effector-mediated competition

7 of Vibrio cholerae. We found that V. cholerae could employ its cell-wall-targeting effector TseH to outcompete

8 the otherwise resistant Escherichia coli and the $V$. cholerae immunity deletion mutant $\Delta$ tsiH when $\mathrm{Ca}^{2+}$ and $\mathrm{Mg}^{2+}$

9 were supplemented. The E. coli $\Delta p h o Q$ mutant was more sensitive to TseH-mediated killing during competition,

10 suggesting the metal-sensing PhoPQ two-component system is protective to E. coli from TseH activity. Using

11 transcriptome analysis, we found multiple stress response systems, including acid stress response, oxidative stress

12 response, and osmotic stress response, were activated in E. coli expressing TseH in comparison with E. coli

13 expressing the inactive mutant $\mathrm{TseH}^{\mathrm{H} 64 \mathrm{~A}}$. The membrane-targeting lipase effector $\mathrm{TseL}$ also exhibited reduced

14 killing against E. coli when divalent cations were removed. In addition, competition analysis of $E$. coli with $V$.

15 cholerae single-effector active strains reveals a temperature-dependent susceptibility of $E$. coli to effectors, VasX,

$16 \mathrm{VgrG}$, and TseL. These findings suggest that abiotic factors, that $V$. cholerae frequently encounters in natural

17 habitats, play a crucial role in dictating the competitive fitness conferred by the type VI secretion system in

18 complex multispecies communities. 
Introduction

Living in complex natural and host environments, microbes frequently compete for limited nutrients and ecological niches. To survive, microbes have evolved multiple effective weapons [1-4], one of which is the type VI protein secretion system (T6SS) commonly found in gram-negative bacteria [5-7]. The T6SS consists of three structural parts, a bacteriophage-like baseplate (TssEFGK), a transmembrane complex (TssJLM), and a contractile-tube structure with the Hcp inner tube surrounded by VipA/VipB outer sheath [8-11]. The top of the T6SS Hcp tube is sharpened by a VgrG trimer-PAAR spike complex [12-14]. Upon sheath contraction, the T6SS could inject the inner tube-spike components and the associated effectors directly into the recipient cells [15-17].

The physical puncture of T6SS injection causes little harm to recipient cells and it is the T6SS effectors that mainly dictate the T6SS function [17-20]. Effectors are T6SS-secreted toxins exhibiting anti-bacterial and/or anti-eukaryotic activities, and the anti-bacterial effectors mainly include cell-wall disrupting effectors, membrane ADP-ribosyl transferase [22], (p)ppApp synthetase [23]. To confer self-protection against anti-bacterial toxins, bacteria encode effector-cognate immunity proteins that specifically interact with effectors [24-27]. In contrast to the specific immunity protein-mediated protection, the innate-immunity-like stress response pathways also provide critical protection against effectors and T6SS delivery, including production of extracellular polysaccharides [18, 28], oxidative stress response [29, 30], envelope stress responses [18], acid and osmotic stress response [19]. In addition, spatial separation at the community level can also protect susceptible cells from T6SS aggressors [3135].

T6SS species often encode multiple effector modules which may be used synergistically toward certain species or independently for killing of a broad spectrum of competitors [36-39]. However, some effectors are inactive under lab conditions. For example, in the cholera-causing pathogen Vibrio cholerae, the cell-wall targeting trans-peptidase TseH shows little toxicity against Escherichia coli or the $V$. cholerae immunity gene deletion mutant $\Delta t s i H$ when it is delivered by the T6SS $[18,40]$. However, TseH is highly toxic to Aeromonas and other waterborne species that $V$. cholerae may encounter in the natural environments [18]. Similarly, the lipase effector 
effective against the $E$. coli prey $[17,19,27]$. The difference in susceptibility has been attributed to the nonspecific stress response mechanisms in diverse bacteria [18-20].

In this study, we report that a number of abiotic environmental factors, including cations, temperatures and antibiotics, also play a crucial role in T6SS-mediated interspecies competition by modulating target-species sensitivity to specific effectors. Using a panel of single-effector active V. cholerae V52 mutants [17, 18], we show that trace amounts of divalent cations, $\mathrm{Mg}^{2+}$ and $\mathrm{Ca}^{2+}$, could stimulate $\mathrm{TseH}$ toxicity against $E$. coli when delivered by the T6SS, and EDTA treatment abolished such stimulation. The V. cholerae $\Delta$ tsiH mutant was also more sensitive to TseH during competition when $\mathrm{Ca}^{2+}$ was supplemented. We further show that deletion of $p h o Q$, encoding the sensor of the key two-component system PhoPQ that senses low $\mathrm{Mg}^{2+}$ [41], renders E. coli more sensitive to TseH-mediated killing, while a constitutively active $\mathrm{PhoQ}{ }^{\mathrm{D} 179 \mathrm{~L}}$ is more resistant. Transcriptome analysis of E. coli expressing TseH or its catalytic mutant $\mathrm{TseH}^{\mathrm{H} 64 \mathrm{~A}}$ in the periplasm shows a global cellular change involving multiple pathways, including acid stress response, oxidative stress response, and osmotic stress response, which might be crucial for survival against TseH toxicity. The toxicity of TseL, a lipase effector in $V$. cholerae, was also modulated by divalent cations since EDTA treatment resulted in significantly reduced E. coli killing mediated by TseL. In addition to cations, V. cholerae effectors, VasX, VgrG3 and TseL, also show temperature-dependent toxicity when delivered individually to $E$. coli. Collectively, our data indicate effectormediated toxicities are modulated by these abiotic factors, highlighting the complex effects of natural environments on interspecies interactions mediated by the T6SS.

\section{Results}

\section{T6SS-delivered TseH is conditionally toxic to $E$. coli depending on agar sources.}

We have previously reported that the $V$. cholerae $\mathrm{seH}^{+}$only mutant, lacking all the other antibacterial effectors, could not outcompete $E$. coli due to the non-specific protections conferred by the envelope stress response pathways [18]. However, we serendipitously found that TseH toxicity was largely affected by the source of agars used for competition. When agar source 1 was used, we reproduced the earlier observation and showed that survival of E. coli competed with the $t s e H^{+}$only mutant was comparable to that competed with the T6SS-null mutant $\Delta$ vasK and the four-effector inactive mutant 4 eff (Figure 1A, Supplementary Figure 1A). However, when 
72 a different source of agar was used (source 2), we noticed that E. coli survival was reduced by 10,000 -fold in competition with the $V$. cholerae $t s e H^{+}$only mutant, relative to that competed with the $4 e f f$ and $\Delta v a s K$ mutant. Survival of $E$. coli remained the same under both agar conditions for samples competed with wild-type V. cholerae, the $\Delta v a s K$, or the $4 e f f_{c}$ mutant, separately.

\section{$\mathrm{Mg}^{2+}$ and $\mathrm{Ca}^{2+}$ stimulate TseH-mediated killing against $\mathrm{E}$. coli.}

To determine the difference between agars that may account for the TseH killing efficiency, we first used XRF (X-Ray Fluorescence) to compare element contents in these two agar samples. XRF results show that Ca and $\mathrm{Mg}$ content were substantially higher in source 2 agar (Supplementary Table 1). Using ICP-MS (Inductively Coupled Plasma Mass Spectrometry), we further quantified $\mathrm{Mg}$ and $\mathrm{Ca}$ content. The $\mathrm{Mg}$ and $\mathrm{Ca}$ content were $85.83 \pm 2.40 \mathrm{mg} / \mathrm{kg}$ and $16.92 \pm 0.30 \mathrm{mg} / \mathrm{kg}$ respectively in source 1 agar. However, in source 2 agar, the $\mathrm{Mg}$ and $\mathrm{Ca}$ content were $515.29 \pm 13.57 \mathrm{mg} / \mathrm{kg}$ and $200.93 \pm 9.29 \mathrm{mg} / \mathrm{kg}$ (Table 1), about 6-fold and 10-fold higher than their levels in source 1 agar, respectively.

To test if the observed high levels of $\mathrm{Mg}$ and $\mathrm{Ca}$ are responsible for the enhanced TseH-mediated killing against E. coli, we supplemented $\mathrm{Mg}^{2+}$ or $\mathrm{Ca}^{2+}$ in source 1 agar to the detected levels and tested their effects on bacterial competition. Indeed, the addition of $\mathrm{Mg}^{2+}$ or $\mathrm{Ca}^{2+}$ stimulated $\mathrm{TseH}$-mediated killing and reduced E. coli survival significantly, with $\mathrm{Ca}^{2+}$ showing a stronger effect (Figure 1B, Supplementary Figure 1B). Notably, the combination of $0.27 \mathrm{mM} \mathrm{Mg}^{2+}$ and $0.07 \mathrm{mM} \mathrm{Ca}^{2+}$, the amount closely resembling the detected levels in source 2 agar (Table 2), did not fully reduce E. coli survival to that in source 2 agar, suggesting other factors in source 2 also contribute to the increased TseH toxicity.

To further confirm that metal ions play a critical role in stimulating TseH-mediated killing against E. coli, we washed the source 2 agar powder with a metal-chelator EDTA solution to remove divalent cations. Results showed that EDTA-washed source 2 agar failed to support TseH-mediated killing, while the deionized water $\left(\mathrm{ddH}_{2} \mathrm{O}\right)$-treated source 2 agar could still stimulate TseH killing (Figure 1C, Supplementary Figure 1C). Both the EDTA-treatment and water-treatment did not support TseH-mediated killing on source 1 agar plates.

Finally, we also used the defined M9 medium for competition between the se $^{+}$mutant and E. coli. Both M9 with source 1 agar and source 2 agar plates supported TseH-mediated killing, with the source 2 agar plate showing a stronger effect (Figure 1D, Supplementary Figure 1D). Because the M9 salt contains $\mathrm{Mg}^{2+}$ and $\mathrm{Ca}^{2+}(1.0$ 
$\mathrm{mM} \mathrm{Ca}{ }^{2+}, 0.1 \mathrm{mM} \mathrm{Mg}^{2+}$ ), we also tested the effects when these two cations were omitted. Results showed that only source 2 agar supported the TseH-mediated killing. Collectively, these results demonstrated that TseHmediated toxicity is largely dependent on environmental $\mathrm{Mg}^{2+}$ and $\mathrm{Ca}^{2+}$ levels.

\section{Conditional toxicity of TseH is also appliable to $\mathrm{V}$. cholerae.}

We have previously reported that deletion of $t s e H$ cognate immunity gene, $t s i H$, did not render the $V$. cholerae mutant susceptible to TseH [40], which is attributed to protection by immunity-independent defense mechanisms, such as the WigKR two-component system [18]. Since E. coli showed different sensitivity against TseH with or without $\mathrm{Mg}^{2+}$ and $\mathrm{Ca}^{2+}$, we asked whether the $V$. cholerae $\Delta t s i H$ mutant would be sensitive to TseH in the presence of these two cations. We constructed a $\Delta t s i H$ deletion mutant lacking the paar2-tseH-tsiH threegene operon in the $4 e f f_{c}$ mutant background and used it as prey for competition against the $t s e H^{+}$strain or the $4 e f f_{c}$ strain, separately. The competition assay results showed that, like $E$. coli, the $\Delta t s i H$ mutant was sensitive to the tse $\mathrm{H}^{+}$strain on source 2 agar plates but not on source 1 agar plates, exhibiting a 10 -fold reduced survival relative to that exposed to the $4 e f f_{c}$ killer strain (Figure 1E, Supplementary Figure 1E). In addition, supplementation of 0.3 $\mathrm{mM} \mathrm{Ca}^{2+}$ to source 1 agar reduced the $\Delta t s i H$ mutant survival significantly, while a combination of $0.27 \mathrm{mM} \mathrm{Mg}^{2+}$ and $0.07 \mathrm{mM} \mathrm{Ca}^{2+}$ or $0.3 \mathrm{mM} \mathrm{Mg}{ }^{2+}$ alone had minor effects. Thus, $\mathrm{Ca}^{2+}$ also stimulated TseH-mediated killing against the $V$. cholerae $\Delta$ tsiH mutant.

\section{The addition of $\mathrm{Mg}^{2+}$ and $\mathrm{Ca}^{2+}$ does not affect T6SS secretion.}

Intrigued by the stimulating effect of $\mathrm{Mg}^{2+}$ and $\mathrm{Ca}^{2+}$ on $\mathrm{TseH}-$ mediated killing, we first hypothesized that $\mathrm{Mg}^{2+}$ and $\mathrm{Ca}^{2+}$ may affect T6SS secretion efficiency. Thus, we compared the secretion of Hcp with or without $\mathrm{Mg}^{2+}$ and $\mathrm{Ca}^{2+}$ as an indicator for T6SS activities. The results showed that Hcp was secreted to the same levels with or without $\mathrm{Mg}^{2+}$ and $\mathrm{Ca}^{2+}$ supplementation between wild type or the $t s e H^{+}$samples, suggesting the addition of $\mathrm{Mg}^{2+}$ and $\mathrm{Ca}^{2+}$ has little effect on the T6SS secretion (Figure 2A, Supplementary Figure2A). 
toxicity is independent of $\mathrm{Mg}^{2+}$ and $\mathrm{Ca}^{2+}$. Taken together, these results indicated that the metal-dependent sensitivity of E. coli to TseH was not caused by difference in $V$. cholerae T6SS secretion nor changed TseH activities under these two conditions.

PhoPQ two-component system contributes to immunity-independent defense against TseH. may be activated to confer protection against $\mathrm{TseH}$, while the supplement of $\mathrm{Mg}^{2+}$ represses such protection. and used competition assay to compare its survival against the $t \mathrm{seH}^{+}$strain. Results showed that the deletion of phoQ made E. coli significantly more sensitive to $\mathrm{TseH}$ even in the absence of $\mathrm{Mg}^{2+}$ and $\mathrm{Ca}^{2+}$ (Figure $3 \mathrm{~A}$, $\triangle p h o Q$ strains when competed with the $t s e H^{+}$mutant with $\mathrm{Mg}^{2+}$ and $\mathrm{Ca}^{2+}$. We also constructed the E. coli $p h o Q^{D 179 L}$ strain, a PhoQ locked-on mutant that constitutively phosphorylates PhoP and activates its regulon genes [44].

Competition analysis showed that this $p h o Q^{D 179 L}$ mutation significantly increased $E$. coli survival relative to the $\triangle p h o Q$ with or without $\mathrm{Mg}^{2+}$ and $\mathrm{Ca}^{2+}$ (Figure 3A). These results suggest that the PhoPQ two-component system also contribute to immunity-independent defense mechanism against TseH toxicities, in addition to the known envelope stress response systems [18].

\section{5}

\section{Transcriptome analysis in $E$. coli periplasmically expressing TseH and its inactive mutant TseH $^{\mathrm{H} 64 \mathrm{~A}}$}

Next, we examined the effect of adding metal cations to E. coli using RNA-seq transcriptome analysis. 
153 survival expressing the non-toxic mutant (Figure 3B), suggesting TseH was expressed in most cells. Under this 154 condition, we performed RNA extraction and performed transcriptome analysis. To identify genes differentially 155 expressed, we set the cut-off value of fold change $>1.5$ and $p$-value $<0.05$. We also removed the low transcriptome 156 gene with an average FPKM (fragments per kilobase per million mapped fragments) < 10. By comparing the 157 transcriptome of these two strains, we found 106 genes were differentially expressed, of which 50 genes were up158 regulated and 56 genes were down-regulated (Figure 3C, Supplementary Figure 3C, Dataset 2).

159 Among the up-regulated genes, 22 genes belonged to the RpoS general stress response regulon, including $160 \operatorname{gadCF}$ and $o s m Y$ (Figure 3D). We also found three small regulatory RNA, gadF, $g \operatorname{lm} Y$ and $o m r B$ were up161 regulated. GadF is involved in acid stress response [45, 46]; GlmY controls the amino sugar metabolism in E. coli 162 by post-transcription and deletion of $g \operatorname{lm} Y$ renders cells sensitive to envelope stress [47]. OmrB is a small RNA 163 that is involved in regulating the protein composition of the outer membrane [48]. Among the down-regulated 164 genes, we found 24 genes belonging to the heat-shock response RpoH regulon were down-regulated, including dnaK, groL, groS, and the protease gene lon. These genes are important for proper protein folding.

We have shown that the T6SS delivered-TseH induces the envelope stress response in E. coli [18]. In the transcriptome results, we found the BaeR regulon gene ycaC was up-regulated. In addition, gadF, also a PhoPQregulated gene, was upregulated. Another PhoPQ-regulated gene $m g r B$, involved in $\mathrm{Mg}^{2+}$ uptake, was up-regulated with $p$-value $<0.05$ but with a moderate fold change $<1.5$.

To validate the RNA-seq data, we performed qRT-PCR assays of 14 genes, of which 7 were up-regulated and 7 were down-regulated. These genes were with the relative high fold change in RNA-seq results. The $16 \mathrm{~S}$ rRNA gene was used as the reference. The qRT-PCR results were consistent with the RNA-seq results (Figure 3E).

\section{4}

\section{Divalent cations contribute to TseL-mediated toxicity.}

We also noticed that another T6SS effector TseL with phospholipase activity in $V$. cholerae, also exhibited different toxicity against $E$. coli on different agar sources during interspecies competition. On source 1 agar plates, the $V$. cholerae $\operatorname{seL}^{+}$mutant reduced E. coli survival by 100 -fold relative to the 4 eff $c$ mutant. In contrast, on source 2 agar plates, the E. coli survival was reduced about 10,000 -fold by the $t s e L^{+}$mutant relative to the 4 eff mutant 
180 TseL-mediated killing difference between the two agar sources (Figure 4B, Supplementary Figure 4B). When

181 comparing E. coli survival on TseL-sensitive agar source 2, we found that EDTA-treatment increased E. coli 182 survival by 100 -fold relative to deionized water-treatment. To further investigate which divalent cations play a 183 role in this process, we competed the $t \mathrm{SeL}^{+}$mutant and $E$. coli on source 1 agar plates supplemented with $0.3 \mathrm{mM}$ $\mathrm{Mg}^{2+}, \mathrm{Ca}^{2+}, \mathrm{Ni}^{2+}$ and $\mathrm{Cu}^{2+}$, respectively. However, unlike $\mathrm{TseH}$, none of the tested cations increased the TseLtoxicity to the agar source 2 levels (Figure 4C, Supplementary Figure 4C). Nonetheless, these results suggest that TseL-mediated toxicity is also modulated by some EDTA-chelatable divalent cations.

\section{Temperature affects effector-mediated competition.}

Since $V$. cholerae may also experience temperature changes in the environment or during transmission from environment to the host, we next determined whether temperature also plays a role in effector-mediated bacterial competition. We used a panel of $V$. cholerae single-effector-active killer strains and E. coli as prey. Results show that the relative survival of E. coli was significantly reduced at $30^{\circ} \mathrm{C}$ in comparison to that at $37^{\circ} \mathrm{C}$ when $E$. coli was competed with the $\operatorname{vas} X^{+}$(with membrane pore-forming activity) and the $\operatorname{vgrG} 3^{+}$(a lysozyme) strains, separately (Figure 4D, Supplementary Figure 4D). In contrast, the survival of E. coli was significantly increased at $30{ }^{\circ} \mathrm{C}$ relative to that at $37{ }^{\circ} \mathrm{C}$ when $E$. coli was competed with the $t s e L^{+}$strain (Figure 4D, Supplementary Figure 4D). These results collectively indicate that temperature also plays an important role in T6SS-mediated competition.

\section{VasX-toxicity in $P$. aeruginosa is dependent on temperature and the antibiotic irgasan.}

We have previously reported that periplasmic expression of VasX using a Tat secretion signal is highly toxic in E. coli but not in Pseudomonas aeruginosa PAO1, an important opportunistic pathogen [19]. We thus tested whether the resistance of $P$. aeruginosa to VasX is also temperature-dependent. First, we confirmed this resistance phenotype by comparing the survival of PAO1 expressing plasmid-borne Tat-VasX or its inactive mutant Tat-VasX $\mathrm{X}^{\Delta \mathrm{C} 16}[17]$ at $37^{\circ} \mathrm{C}$ (Figure 4E). However, when VasX was highly induced at $30{ }^{\circ} \mathrm{C}$, we found that survival of PAO1 was reduced to undetectable levels (Figure 4E). Because the assays were performed on plates containing two antibiotics, irgasan that PAO1 is intrinsically resistant to, and gentamycin whose resistance is conferred by the pTat-VasX plasmid, and because expression of VasX increases membrane permeability [19], we 
207 periplasmic expression of VasX in PAO1 but only plated the induced cells on gentamycin. We found that PAO1 208 became resistant to VasX expression at both $30^{\circ} \mathrm{C}$ and $37^{\circ} \mathrm{C}$ (Supplementary Figure 4E). These results suggest 209 that the membrane damages caused by VasX expression at $30^{\circ} \mathrm{C}$, albeit insufficient to cause cell death directly, 210 can disturb the intrinsic resistance of P. aeruginosa to irgasan (Figure 4E, Supplementary Figure 4E).

\section{Discussion}

Microbes have been found in almost all ecological niches on earth and contribute to a variety of functions 214 ranging from macroscale carbon recycling and waste removal to individual-level host health and disease. These 215 functions are often determined by not a single but multiple species that coexist in complex communities, with 216 extensive interspecies interactions via various molecular mechanisms. The T6SS is one such crucial mechanism 217 exhibiting anti-bacterial, anti-fungal and other anti-eukaryotic functions [5, 24, 49-51]. From a molecular 218 ecological perspective, the T6SS-mediated interspecies competition is a complex and multifaced process whose outcome is determined by diverse factors including the number and type of the secreted effectors [31], the frequency of T6SS firing correlated with energy state [31], the immunity protein-dependent specific protection [24], the non-specific stress response pathways in killer and prey cells [18, 20], and the availability of nutrients [52][53]. Here, we add on to this list by showing that abiotic environmental factors can modulate prey cell sensitivity to effector toxicities, thereby affecting T6SS-mediated competition (Figure 6). Our results demonstrate not only that some seemingly inactive effectors may be highly toxic in natural settings but also the importance of examining toxin-mediated interspecies interactions beyond the routine lab conditions. ecological functions of the T6SS. An elegant strategy employing barcoding-sequencing analysis of mixed effectorsusceptible populations in $P$. aeruginosa reveals that effectors may act jointly with other effectors to exert synergistic functions but their activities can also be variable depending on salinity, $\mathrm{pH}$ and aerobic conditions [39]. 231 Here we show the ecologically-relevant abiotic factors, including cations and temperature, that microbes 232 frequently encounter in nature environment, play a critical role in mediating T6SS-dependent interspecies killing. 233 Our previous study on the $V$. cholerae T6SS effector TseH reveals that E. coli mutants impaired in envelope stress 
234 response (ESR) pathways, but not the wild type, are sensitive to TseH toxicities [18]. Here we show that 235 supplementation of $\mathrm{Mg}^{2+}$ and $\mathrm{Ca}^{2+}$ cations can render E. coli susceptible to TseH despite of the intact ESR 236 protection. Another effector TseL has also exhibited cation-related toxicity since EDTA-treatment of the agar 237 could reduce TseL-mediated killing against E. coli. Notably, as V. cholerae is a waterborne pathogen commonly 238 found in water sources in which $\mathrm{Mg}^{2+}$ (average concentration $\left.50 \mathrm{mM}\right)$ and $\mathrm{Ca}^{2+}(\sim 10 \mathrm{mM})$ are present at much 239 higher levels than the levels supplemented here [54], the $V$. cholerae T6SS effectors may have a broader target 240 range in the natural niche. Indeed, when a source of raw agar was used, we also found highly increased TseH241 mediated killing against E. coli (Figure 5A, 5B, Supplementary Figure 5A, 5B). $\mathrm{Mg}^{2+}$ and $\mathrm{Ca}^{2+}$ are known to have critical cellular functions, but the effect of cations on T6SS effector toxicities in prey cells has not been reported before. As the most abundant divalent cation in living cells, $\mathrm{Mg}^{2+}$ neutralizes the negative charge of biomolecules, including nucleotides and nucleic acids, phospholipids in various membrane structures in cells, as well as serving as an indispensable cofactor in various enzymes $[41,55,56]$. Like $\mathrm{Mg}^{2+}, \mathrm{Ca}^{2+}$ could also maintain cell structure, participate in motility and cell division processes [57, 58]. Due to the critical role $\mathrm{Mg}^{2+}$ and $\mathrm{Ca}^{2+}$ play in bacteria, the concentrations of $\mathrm{Mg}^{2+}$ and $\mathrm{Ca}^{2+}$ are tightly regulated $[56,59]$. Under low $\mathrm{Mg}^{2+}$ conditions, the two component system PhoPQ is activated to regulate a large number of genes involved in virulence, metal uptake, and other important functions $[41,56]$. The increased resistance of $E$. coli to TseH in agar source 1 with lower $\mathrm{Mg}^{2+}$ may thus be attributed to activation of PhoPQ. Indeed, deletion of $p h o Q$ leads to increased sensitivity to TseH, suggesting that the PhoPQ-system is important for such protection (Figure $3 \mathrm{~A})$.

Although we have yet to determine the exact physiological changes in prey cells that account for the temperature and cation-dependent effector-mediated competition, it is likely a multifaceted process that involves a number of different cellular pathways, as exemplified in the transcriptome changes upon TseH induction (Figure 3C, 3D). Given the prevalence of T6SS organisms, including plant and host pathogens, as well as the diversity of effectors in each species, it is crucial to take into account of ecologically relevant conditions for testing T6SSrelated effector functions and interspecies interactions in future studies. The environmental cues, such as cations and temperature, may have profound effects on the composition of T6SS-containing microbial communities and the evolution of their defense and attack mechanisms. 


\section{Methods}

\section{3}

\section{Strains and growth conditions}

Strains and plasmids used in this study are described in Supplementary Table 2. All constructs were verified by sequencing. Primers are available in Dataset 3. Bacteria were grown in $\mathrm{LB}([\mathrm{w} / \mathrm{v}] 1 \%$ tryptone, $0.5 \%$ yeast extract, $0.5 \% \mathrm{NaCl}$ ) at $37{ }^{\circ} \mathrm{C}$ aerobically. Antibiotics and inducers were used at following concentrations: kanamycin $(25 \mu \mathrm{g} / \mathrm{mL}$ for E. coli, $50 \mu \mathrm{g} / \mathrm{mL}$ for $V$. cholerae and A. dhakensis), streptomycin $(100 \mu \mathrm{g} / \mathrm{mL})$, chloramphenicol $(2.5 \mu \mathrm{g} / \mathrm{mL}$ for $V$. cholerae and $25 \mu \mathrm{g} / \mathrm{mL}$ for $E$. coli $)$, irgasan $(25 \mu \mathrm{g} / \mathrm{mL})$, gentamycin $(20$ $\mu \mathrm{g} / \mathrm{mL}), \mathrm{L}$-arabinose ([w/v] $0.1 \%$ or $0.01 \%$ as indicated), IPTG $(0.1 \mathrm{mM}$ or $1 \mathrm{mM}$ as indicated). Tryptone (BIO BASIC, TG217(G211)), yeast extract (BIO BASIC, G0961), source 1 agar (BIO BASIC, FB0010), source 2 Agar (Sangon Biotech, A505255-0250).

\section{EDTA treatment of agar powder}

Agar powders were washed by $0.1 \mathrm{M}$ EDTA solution for $5 \mathrm{~min}$ with vortex, followed by deionized water washing with 5 times to remove EDTA. Then the treated agar was dried and could be used for bacterial competition experiments.

\section{Bacterial competition assay}

Competing strains were grown overnight in LB with appropriate antibiotics. Killer cells were then subcultured to $\mathrm{OD}_{600}=1$. For interspecies competition, killer and prey cells were mixed at a ratio of 5:1 and coincubated on LB-agar plates or M9-agar $\left(93.0 \mathrm{mM} \mathrm{Na}^{+}, 22.1 \mathrm{mM} \mathrm{K}^{+}, 18.7 \mathrm{mM} \mathrm{NH}_{4}^{+}, 1.0 \mathrm{mM} \mathrm{Ca}^{2+}, 0.1 \mathrm{mM}\right.$ $\mathrm{Mg}^{2+}, 29.2 \mathrm{mM} \mathrm{Cl}^{-}, 0,1 \mathrm{mM} \mathrm{SO}_{4}{ }^{2-}, 42.2 \mathrm{mM} \mathrm{PO}_{4}{ }^{2-},[\mathrm{w} / \mathrm{v}] 0.1 \%$ glucose) plates at $37^{\circ} \mathrm{C}$ or $30^{\circ} \mathrm{C}$ (as indicated) for $3 \mathrm{~h}$. For intraspecies competition, killer and prey cells were mixed at a ratio of 20:1 and co-incubated on LBagar plates at $37^{\circ} \mathrm{C}$ for $20 \mathrm{~h}$ (or $3 \mathrm{~h}$ when using raw agar). After co-incubation, the survival of killer and prey cells were enumerated by 10 -fold serial plating on LB plates with selective antibiotics. The mean $\log _{10}$ c.f.u of the recovered killer and prey strains was plotted and error bars show the mean \pm standard deviation of at least three biological replicates. A two-tailed Student's $t$-test and one-way ANOVA test was used to determine $p$ values.

\section{XRF and ICP analysis}


XRF (X-Ray Fluorescence) and ICP (Inductively Coupled Plasma Mass Spectrometry) analysis was done by the Instrumental Analysis Center in Shanghai Jiao Tong university. For XRF analysis, the agar powder was pressed into disks (30 mm diameter) and performed with a XRF (XRF-1800, SHIMADZU). For ICP analysis, the two agar samples were digested with $5 \mathrm{~mL}$ concentrated nitric acid and diluted to $50 \mathrm{~mL}$ with ultrapure water. After samples were prepared, elemental analysis was performed with an ICP (Avio 500, PerkinElmer).

\section{Protein secretion assay}

Strains were grown overnight in LB with appropriate antibiotics. Cells were then sub-cultured to $\mathrm{OD}_{600}=1$ with or without $\mathrm{Mg}^{2+}$ and $\mathrm{Ca}^{2+} .2 \mathrm{ml}$ of $\mathrm{OD}_{600} 1$ cells were collected by centrifuge at 2,500 $\times g$ for $3 \mathrm{~min}$ and resuspended in $1 \mathrm{~mL}$ fresh LB. Resuspended cells were placed at $30{ }^{\circ} \mathrm{C}$ for $1 \mathrm{~h}$ and centrifuged at $10,000 \times g$ for at $10,000 \times g$ for 2 min again as the secretion sample. All samples were mixed with SDS-loading dye, boiled at $98{ }^{\circ} \mathrm{C}$ for $10 \mathrm{~min}$, followed by SDS-PAGE (sodium dodecyl sulfate polyacrylamide gel electrophoresis) analysis and Western blotting analysis.

\section{Western blotting analysis}

After electrophoresis in a $12 \%$ SDS-PAGE gel, proteins were transferred to a PVDF membrane (Bio-Rad).

Then, the protein-bound membrane was blocked with 5\% [w/v] non-fat milk in TBST (50 mM Tris, $150 \mathrm{mM}$

$\mathrm{NaCl}, 0.1 \%[\mathrm{v} / \mathrm{v}]$ Tween-20, $\mathrm{pH}$ 7.6) buffer for $1 \mathrm{~h}$ at $\mathrm{RT}$. After blocking, the membrane was sequentially incubated with primary and secondary HRP (horseradish peroxidase)-conjugated antibodies in TBST with $1 \%$ [w/v] milk for $1 \mathrm{~h}$ at RT. Signals were detected using the Clarity ECL solution (Bio-Rad). The monoclonal antibody to RpoB, the beta subunit of RNA polymerase, were purchased from Biolegend (RpoB, Product \# 663905). The polyclonal antibody to Hcp was custom-made by Shanghai Youlong Biotech. The HRP-linked secondary antibodies were purchased from ZSGB-Bio (Product \# ZB-2305 (mouse) and \# ZB-2301 (rabbit)).

310 The Hcp antibody was used at 1:10000 dilution, while others at 1:20000 dilution.

\section{Toxicity assay}

312 For VasX toxicity assay in PAO1, overnight cells carrying pPSV37 constructs were grown in LB with 313 appropriate antibiotics and $0.2 \%$ [w/v] glucose at $37^{\circ} \mathrm{C}$. Cells were then collected and resuspended in fresh LB. 
314 A serial dilution was plated on LB plates containing $0.1 \mathrm{mM}, 1 \mathrm{mM}$ IPTG or $0.2 \%$ [w/v] glucose with antibiotics 315 as indicated.

\section{RNA sample preparation}

317 For transcriptome analysis of E. coli with or without $\mathrm{Mg}^{2+}$, exponential-phase-growing E. coli cells were 318 collected and transferred onto LB plates with or without $0.3 \mathrm{mM} \mathrm{Mg}^{2+}$ for $30 \mathrm{~min}$ prior to RNA extraction. For 319 transcriptome analysis of $E$. coli ectopically expressing Tat-TseH and its inactive mutant Tat-TseH ${ }^{\mathrm{H} 64 \mathrm{~A}}$, E. coli 320 strains with pBAD24kan-Tat-TseH/TseH ${ }^{\mathrm{H} 64 \mathrm{~A}}$ plasmid were grown overnight on LB plates with appropriate 321 antibiotics and $0.2 \%[\mathrm{w} / \mathrm{v}]$ glucose. Cells were then sub-cultured to $\mathrm{OD}_{600}=1$, collected by centrifugation at $32210,000 \times g$ for $0.5 \mathrm{~min}$ and washed twice with fresh LB. After being recovered at $37^{\circ} \mathrm{C}$ for 10 min, cells were 323 induced with $0.1 \%$ [w/v] arabinose for $30 \mathrm{~min}$ followed by total RNA extraction. The survival of E. coli strains 324 after induction was enumerated by 10 -fold serial plating on LB plates with selective antibiotics and $0.2 \%$ [w/v] 325 glucose.

RNA extraction

$100 \mu \mathrm{L} 8 \times$ lysis buffer (8\% [w/v] SDS, $16 \mathrm{mM}$ EDTA) was added into $700 \mu \mathrm{L}$ culture of each sample after induction and mixed well by vortex for $5 \mathrm{~s}$. Then $800 \mu \mathrm{L}$ prewarmed hot acidic phenol $\left(65^{\circ} \mathrm{C}\right)$ was added and mixed by inverting immediately. Tubes were incubated at $65^{\circ} \mathrm{C}$ for $5 \mathrm{~min}$ with mixing briefly every $1 \mathrm{~min}$. After putting on ice for $10 \mathrm{~min}$, the mixture was centrifuged at $13,000 \times g$ for $2 \mathrm{~min}$. The top supernatant was carefully transferred to a new tube and an equal-volume of absolute ethanol was added. Then the crude RNA was purified by RNA prep Pure Cell/Bacteria Kit (TIANGEN, Product \#DP430) and genomic DNA was removed by DNase I (NEB, Product B0303S) treatment at $37^{\circ} \mathrm{C}$ for $30 \mathrm{~min}$. After DNase I treatment, RNA samples were then purified with the RNA clean Kit (TIANGEN, Product \#DP421). Purified RNA was electrophoresed on 1\% [w/v] agarose gel to monitor the integrity and contaminants.

\section{Transcriptome analysis}


341 stranded cDNA was end-repaired, adding an A tail and connecting to the sequencing adapter. USER enzyme 342 (NEB, USA) was used to degrade the second strand of cDNA containing U. After using AMPure XP beads to 343 screen cDNA with 370 420 bp and PCR amplification of these fragments, the final library was obtained with 344 another cycle of AMPure XP beads purification. The clustering of the index-coded samples was performed on a 345 cBot Cluster Generation System following to the manufacturer's instructions, and the sequencing was performed 346 using the Illumina Hiseq TM 2500 platform with pair-end 150 base reads. Raw data was filtered according to the 347 following standards: (1) removing reads with unidentified nucleotides $(\mathrm{N})$; (2) removing reads with low 348 sequencing quality ( $>50 \%$ bases having Phred quality scores of $\leqslant 20$ ); (3) removing reads with the adapter. The 349 obtained clean data were used for downstream analysis. Bowtie2-2.2.3 was used to build an index of the 350 reference genome and align clean reads to reference genome. The gene expression level was calculated and 351 further normalized by HTSeq v0.6.1. FPKM, fragments per kilobase of transcript sequence per millions base 352 pairs sequenced, was used to demonstrated gene expression level here.

\section{Bioinformatics Analysis}

Differential expression genes were identified by setting cut-off value of fold change $>1.5, p$-value $<0.05$. and average FPKM > 10. PCA analysis was performed by R package FactoMineR. Person correlation coefficient was calculated by R package WGCNA. Heat map was performed in Origin App: Heat map with Dendrogram. qRT-PCR Analysis

14 differential expression genes were chosen from transcriptome results. Primers for qPCR were designed by PerlPrimer. The 16S rRNA gene was used as the reference. Reverse transcription was done using PrimeScript ${ }^{\mathrm{TM}}$ RT reagent Kit with gDNA Eraser (Perfect Real Time) (Takara, \#RR047A). qPCR reaction was prepared by TB Green ${ }^{\circledR}$ Premix Ex Taq ${ }^{\text {TM }}$ (Tli RNaseH Plus) (Takara, \#RR420A) and detected by CFX Connect Real-Time PCR Detection System (BIO-RAD, \#1855201). Analysis of relative gene expression was calculated using the $2^{-\Delta \Delta C T}$ method. Each sample was measured in triplicate and repeated at least three times.

\section{Data availability}

365 The data that support the findings of this study are available within the paper or available from the corresponding 366 author upon reasonable request.

\section{References}


1. Chassaing B, Cascales E. Antibacterial weapons: targeted destruction in the microbiota. Trends Microbiol 2018; 26: 329-338.

2. Aoki SK, Pamma R, Hernday AD, Bickham JE, Braaten BA, Low DA. Contact-dependent inhibition of growth in Escherichia coli. Science 2005; 309: 1245-1248.

3. Taylor NMI, van Raaij MJ, Leiman PG. Contractile injection systems of bacteriophages and related systems. Mol Microbiol 2018; 108: 6-15.

4. Kohanski MA, Dwyer DJ, Collins JJ. How antibiotics kill bacteria: from targets to networks. Nat Rev Microbiol 2010; 8: 423-435.

5. Pukatzki S, Ma AT, Sturtevant D, Krastins B, Sarracino D, Nelson WC, et al. Identification of a conserved bacterial protein secretion system in Vibrio cholerae using the Dictyostelium host model system. Proc Natl Acad Sci U S A 2006; 103: 1528-1533.

6. Mougous JD, Cuff ME, Raunser S, Shen A, Zhou M, Gifford CA, et al. A virulence locus of Pseudomonas aeruginosa encodes a protein secretion apparatus. Science (80- ) 2006; 312: 1526-30.

7. Bingle LE, Bailey CM, Pallen MJ. Type VI secretion: a beginner's guide. Curr Opin Microbiol 2008; 11: 3-8.

8. Basler M, Pilhofer M, Henderson GP, Jensen GJ, Mekalanos JJ. Type VI secretion requires a dynamic contractile phage tail-like structure. 2012.

9. Durand E, Nguyen VS, Zoued A, Logger L, Péhau-Arnaudet G, Aschtgen M-S, et al. Biogenesis and structure of a type VI secretion membrane core complex. Nature 2015; 523: 555-560.

10. Zoued A, Durand E, Brunet YR, Spinelli S, Douzi B, Guzzo M, et al. Priming and polymerization of a bacterial contractile tail structure. Nature 2016; 531: 59-63.

11. Kudryashev M, Wang RYR, Brackmann M, Scherer S, Maier T, Baker D, et al. Structure of the Type VI secretion system contractile sheath. Cell 2015; 160: 952-962.

12. Shneider MM, Buth SA, Ho BT, Basler M, Mekalanos JJ, Leiman PG. PAAR-repeat proteins sharpen and diversify the type VI secretion system spike. Nature 2013; 500: 350-353.

13. Pukatzki S, Ma AT, Revel AT, Sturtevant D, Mekalanos JJ. Type VI secretion system translocates a phage tail spike-like protein into target cells where it cross-links actin. Proc Natl Acad Sci U S A 2007; 104: 15508-15513.

14. Leiman PG, Basler M, Ramagopal UA, Bonanno JB, Sauder JM, Pukatzki S, et al. Type VI secretion apparatus and phage tail-associated protein complexes share a common evolutionary origin. 2009.

15. Vettiger A, Basler M. Type VI secretion system substrates are transferred and reused among sister cells. Cell 2016; 167: 99-110.e12.

16. Ho BT, Fu Y, Dong TG, Mekalanos JJ. Vibrio cholerae type 6 secretion system effector trafficking in target bacterial cells. Proc Natl Acad Sci U S A 2017; 114: 9427-9432.

17. Liang X, Kamal F, Pei TT, Xu P, Mekalanos JJ, Dong TG. An onboard checking mechanism ensures effector delivery of the type VI secretion system in Vibrio cholerae. Proc Natl Acad Sci U S A 2019; 116: 23292-23298.

18. Hersch SJ, Watanabe N, Stietz MS, Manera K, Kamal F, Burkinshaw B, et al. Envelope stress responses defend against type six secretion system attacks independently of immunity proteins. Nat Microbiol 2020; 5: 706-714.

19. Kamal F, Liang X, Manera K, Pei TT, Kim H, Lam LG, et al. Differential Cellular Response to Translocated Toxic Effectors and Physical Penetration by the Type VI Secretion System. Cell Rep 2020; 31: 107766.

20. Hersch SJ, Manera K, Dong TG. Defending against the Type Six Secretion System: beyond Immunity Genes. Cell Rep 2020; 33: 108259.

21. Whitney JC, Quentin D, Sawai S, LeRoux M, Harding BN, Ledvina HE, et al. An Interbacterial $\mathrm{NAD}(\mathrm{P})+$ Glycohydrolase Toxin Requires Elongation Factor Tu for Delivery to Target Cells. Cell 2015; 163: 607-619.

22. Ting SY, Bosch DE, Mangiameli SM, Radey MC, Huang S, Park YJ, et al. Bifunctional Immunity Proteins Protect Bacteria against FtsZ-Targeting ADP-Ribosylating Toxins. Cell 2018; 175: 13801392.e14.

23. Ahmad S, Wang B, Walker MD, Tran HKR, Stogios PJ, Savchenko A, et al. An interbacterial toxin inhibits target cell growth by synthesizing (p)ppApp. Nature 2019; 575: 674-678. 
24. Hood RD, Singh P, Hsu F, Güvener T, Carl MA, Trinidad RRS, et al. A type VI secretion system of Pseudomonas aeruginosa targets a toxin to bacteria. Cell Host Microbe 2010; 7: 25-37.

25. Russell AB, Hood RD, Bui NK, Leroux M, Vollmer W, Mougous JD. Type VI secretion delivers bacteriolytic effectors to target cells. Nature 2011; 475: 343-349.

26. Brooks TM, Unterweger D, Bachmann V, Kostiuk B, Pukatzki S. Lytic activity of the Vibrio cholerae type VI secretion toxin VgrG-3 is inhibited by the antitoxin TsaB. J Biol Chem 2013; 288: 7618-7625.

27. Dong TG, Ho BT, Yoder-Himes DR, Mekalanos JJ. Identification of T6SS-dependent effector and immunity proteins by Tn-seq in Vibrio cholerae. Proc Natl Acad Sci U S A 2013; 110: 2623-2628.

28. Toska J, Ho BT, Mekalanos JJ. Exopolysaccharide protects Vibrio cholerae from exogenous attacks by the type 6 secretion system. Proc Natl Acad Sci U S A 2018; 115: 7997-8002.

29. Dong TG, Dong S, Catalano C, Moore R, Liang X, Mekalanos JJ. Generation of reactive oxygen species by lethal attacks from competing microbes. Proc Natl Acad Sci U S A 2015; 112: 2181-2186.

30. Storey D, Id AM, Mia A, Graca J, Id S, Rodriguez-escudero I, et al. Klebsiella pneumoniae type VI secretion system-mediated microbial competition is PhoPQ controlled and reactive oxygen species dependent. PLoS Pathogens . 2020.

31. Wong MJQQ, Liang X, Smart M, Tang L, Moore R, Ingalls B, et al. Microbial herd protection mediated by antagonistic interaction in polymicrobial communities. Appl Environ Microbiol 2016; 82: 6881-6888.

32. Borenstein DB, Ringel P, Basler M, Wingreen NS. Established Microbial Colonies Can Survive Type VI Secretion Assault. PLoS Comput Biol 2015; 11: 1-16.

33. McNally L, Bernardy E, Thomas J, Kalziqi A, Pentz J, Brown SP, et al. Killing by Type VI secretion drives genetic phase separation and correlates with increased cooperation. Nat Commun 2017; 8: 14371.

34. Cardarelli L, Saak C, Gibbs KA. Two Proteins Form a Heteromeric Bacterial Self-Recognition Complex in Which Variable Subdomains Determine Allele-Restricted Binding. MBio 2015; 6: e00251.

35. Smith WPJ, Vettiger A, Winter J, Ryser T, Comstock LE, Basler M, et al. The evolution of the type VI secretion system as a disintegration weapon. PLoS Biol 2020; 18: 1-26.

36. Russell AB, Peterson SB, Mougous JD. Type VI secretion system effectors: Poisons with a purpose. Nat Rev Microbiol 2014; 12: 137-148.

37. Ho BT, Dong TG, Mekalanos JJ. A view to a kill: the bacterialtype VI secretion system. Cell Host Microbe 2014; 15: 9-21.

38. Jurènas D, Journet L. Activity, delivery, and diversity of Type VI secretion effectors. Mol Microbiol $2020 ; 1-12$.

39. LaCourse KD, Peterson SB, Kulasekara HD, Radey MC, Kim J, Mougous JD. Conditional toxicity and synergy drive diversity among antibacterial effectors. Nat Microbiol 2018; 3: 440-446.

40. Altindis E, Dong T, Catalano C, Mekalanos J. Secretome analysis of Vibrio cholerae type VI secretion system reveals a new effector-immunity pair. MBio 2015; 6: e00075-15.

41. García Véscovi E, Soncini FC, Groisman EA. $\mathrm{Mg}^{2+}$ as an extracellular signal: environmental regulation of Salmonella virulence. Cell 1996; 84: 165-174.

42. Kato A, Tanabe H, Utsumi R. Molecular characterization of the PhoP-PhoQ two-component system in Escherichia coli $\mathrm{K}-12$ : Identification of extracellular $\mathrm{Mg}^{2+}$-responsive promoters. J Bacteriol 1999; 181: 5516-5520.

43. Minagawa S, Ogasawara H, Kato A, Yamamoto K, Eguchi Y, Oshima T, et al. Identification and molecular characterization of the $\mathrm{Mg}^{2+}$ stimulon of Escherichia coli. J Bacteriol 2003; 185: 3696-3702.

44. Minagawa S, Okura R, Tsuchitani H, Hirao K, Yamamoto K, Utsumi R. Isolation and molecular characterization of the locked-on mutant of $\mathrm{Mg}^{2+}$ sensor PhoQ in Escherichia coli. Biosci Biotechnol Biochem 2005; 69: 1281-1287.

45. Melamed S, Peer A, Faigenbaum-Romm R, Gatt YE, Reiss N, Bar A, et al. Global Mapping of Small RNA-Target Interactions in Bacteria. Mol Cell 2016; 63: 884-897.

46. Hommais F, Krin E, Coppée JY, Lacroix C, Yeramian E, Danchin A, et al. GadE (YhiE): A novel activator involved in the response to acid environment in Escherichia coli. Microbiology 2004; 150: 6172.

47. Hobbs EC, Astarita JL, Storz G. Small RNAs and small proteins involved in resistance to cell envelope stress and acid shock in Escherichia coli: Analysis of a bar-coded mutant collection. J Bacteriol 2010; 192: 59-67. 
48. Guillier M, Gottesman S. Remodelling of the Escherichia coli outer membrane by two small regulatory RNAs. Mol Microbiol 2006; 59: 231-247.

49. MacIntyre DL, Miyata ST, Kitaoka M, Pukatzki S. The Vibrio cholerae type VI secretion system displays antimicrobial properties. Proc Natl Acad Sci 2010; 107: 19520-19524.

50. Trunk K, Peltier J, Liu YC, Dill BD, Walker L, Gow NAR, et al. The type VI secretion system deploys antifungal effectors against microbial competitors. Nat Microbiol 2018; 3: 920-931.

51. Ma AT, McAuley S, Pukatzki S, Mekalanos JJ. Translocation of a Vibrio cholerae Type VI Secretion Effector Requires Bacterial Endocytosis by Host Cells. Cell Host Microbe 2009; 5: 234-243.

52. Yu M, Wang YC, Huang CJ, Ma LS, Lai EM. Agrobacterium tumefaciens deploys a versatile antibacterial strategy to increase its competitiveness. J Bacteriol 2021; 203: 1-15.

53. Crisan C V., Nichols HL, Wiesenfeld S, Steinbach G, Yunker PJ, Hammer BK. Glucose confers protection to Escherichia coli against contact killing by Vibrio cholerae. Sci Rep 2021; 11: 1-11.

54. Mewes A, Langer G, de Nooijer LJ, Bijma J, Reichart G-J. Effect of different seawater $\mathrm{Mg}^{2+}$ concentrations on calcification in two benthic foraminifers. Mar Micropaleontol 2014; 113: 56-64.

55. Pontes MH, Sevostyanova A, Groisman EA. When Too Much ATP Is Bad for Protein Synthesis. J Mol Biol 2015; 427: 2586-2594.

56. Groisman EA, Hollands K, Kriner MA, Lee EJ, Park SY, Pontes MH. Bacterial $\mathrm{Mg}^{2+}$ homeostasis, transport, and virulence. Annu Rev Genet 2013; 47: 625-646.

57. Smith RJ. Calcium and Bacteria. Adv Microb Physiol 1995; 37: 83-133.

58. Dominguez DC. Calcium signalling in bacteria. Mol Microbiol 2004; 54: 291-297.

59. Gangola P, Rosens BP. Maintenance of Intracellular Calcium in Escherichia coli. 1987; 262: 1257012574. 


\section{Competing interests}

370 The authors declare no competing interests.

\section{Acknowledgements}

372 This work was supported by funding from National Key R\&D Program of China (2018YFA0901200), National

373 Natural Science Foundation of China (31770082 and 32030001), Canadian Institutes of Health Research,

374 Natural Sciences and Engineering Research Council of Canada, and Canada Research Chair program. The

375 funders had no role in study design, data collection and interpretation, or the decision to submit the work for

376 publication.

\section{Author contributions}

378 T.D. conceived the project. M.T. performed most of the experiment and data analysis. T.P., Z.W., and H.L.

379 performed experiments. X.W. contributed to RNA-seq data analysis. M.T. prepared the first draft. T.D. 380 contributed to the revision with assistance from M.T. and T.P..

\section{Correspondence and request for materials should be addressed to T. Dong.}


bioRxiv preprint doi: https://doi.org/10.1101/2021.05.27.445954; this version posted May 27, 2021. The copyright holder for this preprint (which was not certified by peer review) is the author/funder. All rights reserved. No reuse allowed without permission.

Table 1. Determination of $\mathrm{Mg}$ and $\mathrm{Ca}$ in agar powder by ICP-MS

\begin{tabular}{lll}
\hline & $\mathrm{Mg}(\mathrm{mg} / \mathrm{kg})$ & $\mathrm{Ca}(\mathrm{mg} / \mathrm{kg})$ \\
\hline Agar (Source 1) & $85.83 \pm 2.40$ & $16.92 \pm 0.30$ \\
Agar (Source 2) & $515.29 \pm 13.57$ & $200.93 \pm 9.29$ \\
\hline
\end{tabular}

Table 2. Content of $\mathrm{Mg}$ and $\mathrm{Ca}$ in $\mathrm{LB}$ plates with $1.3 \%$ agar

\begin{tabular}{lll}
\hline & $\mathrm{Mg}(\mu \mathrm{mol} / \mathrm{L})$ & $\mathrm{Ca}(\mu \mathrm{mol} / \mathrm{L})$ \\
\hline Agar (Source 1) & $46.04 \pm 1.30$ & $5.50 \pm 0.10$ \\
Agar (Source 2) & $279.16 \pm 7.35$ & $65.30 \pm 3.02$ \\
\hline
\end{tabular}




\section{$383 \quad$ Figure legends}

384 Figure 1. $\mathrm{Mg}^{2+}$ and $\mathrm{Ca}^{2+}$ stimulate TseH-mediated killing against $\mathrm{E}$. coli and the $\mathrm{V}$. cholerae $\Delta$ tsiH mutant. 385 A, Survival of $E$. coli after competition with $V$. cholerae strains on LB plates of two different agar sources. B, 386 Survival of E. coli competed with $V$. cholerae strains on LB plates of agar source 1, supplemented with $\mathrm{Mg}^{2+}$ and $387 \mathrm{Ca}^{2+}$. C, Effect of EDTA-treatment on survival of E. coli competed with $V$. cholerae strains. LB plates of ddH $\mathrm{H}_{2} \mathrm{O}-$ 388 treated agar were used as control. D, Survival of $E$. coli competed with $V$. cholerae strains on M9 source-1-agar 389 or source-2-agar plates. E, Survival of the $V$. cholerae $\Delta t s i H$ mutant after competition with the $4 e f f_{c}$ and $t s e H^{+}$ 390 strain. For A to E, killer strains are indicated at the bottom of each panel. WT, wild type; $\Delta v a s K$, the T6SS-null $391 \Delta$ vasK mutant; 4 eff c, the 4-antibacterial-effector-inactive mutant; $t s e H^{+}$, the TseH-active mutant. Survival of prey 392 cells was enumerated by serial plating on selective medium. Killer survival was shown in Supplementary Figure 393 1A-1E respectively. Error bars indicate the mean \pm standard deviation of three biological replicates. Statistical 394 significance was calculated using a two-tailed Student's $t$-test for two groups comparison or one-way ANOVA 395 test for more than two groups comparison. ns, not significant; *, $p<0.05 ; * *, p<0.01 ; * * *, p<0.001 ; * * * *, p<$ 396 0.0001. DL, detection limit.

397 Figure 2. Addition of $\mathbf{M g}^{2+}$ and $\mathbf{C a}^{2+}$ does not affect T6SS secretion. A, Secretion analysis of Hcp in V. cholerae 398 strains with or without $\mathrm{Mg}^{2+}$ and $\mathrm{Ca}^{2+}$. WT, wild type; $\Delta v a s K$, the T6SS-null $\Delta v a s K$ mutant; $t s e H^{+}$, the $t s e H^{+}$only 399 mutant. (-), no cations addition; (+), addition of $0.27 \mathrm{mM} \mathrm{Mg}^{2+}$ and $0.07 \mathrm{mM} \mathrm{Ca}^{2+}$. RpoB, the beta subunit of 400 DNA-directed RNA polymerase, serves as cell autolysis and loading control. Full images were shown in 401 Supplementary Figure 2A. B, Survival of the Aeromonas dhakensis SSU $\Delta v a s K$ mutant after competition with $402 V$. cholerae strains, as indicated. WT, wild type; $\Delta v a s K$, the T6SS-null $\Delta v a s K$ mutant; 4eff c, the 4-antibacterial403 effector-inactive mutant; $\mathrm{seH}^{+}$, the TseH-active mutant. Survival of prey strains was enumerated by serial plating 404 on selective medium. Killer survival was shown in Supplementary Figure 2B. Error bars indicate the mean \pm standard deviation of three biological replicates. Statistical significance was calculated using a two-tailed Student's $t$-test. ns, not significant; $* *, p<0.01$. DL, detection limit. 
410 on selective medium. Killer survival was shown in Supplementary Figure 3A. B, Survival of E. coli ectopically 411 expressing $\mathrm{TseH}$ and its inactive mutant $\mathrm{TseH}^{\mathrm{H} 64 \mathrm{~A}}$ with a periplasmic localization Tat signal. Cells were induced 412 with $0.1 \%[\mathrm{w} / \mathrm{v}]$ arabinose and survival was enumerated by serial plating on plates with $0.2 \%$ [w/v] glucose. C, 413 Volcano plot of RNA-seq results in E. coli samples ectopically expressing Tat-TseH and its inactive mutant Tat$414 \mathrm{TseH}^{\mathrm{H} 64 \mathrm{~A}}$. Differential expression genes were screened by setting cut-off value with fold change $>1.5, p$-value $<$ 4150.05 and an average FPKM $>10$. Up and down-regulated genes were indicated in red and green, respectively. 416 Genes with no significant change were indicated in gray. D, Cluster analysis and heat map of differential expression 417 mRNAs in E. coli samples ectopically expressing Tat-TseH and its inactive mutant Tat-TseH ${ }^{\mathrm{H} 64 \mathrm{~A}}$. Scale means the 418 normalized FPKM of each sample by Z-score. E, qRT-PCR verification of differential expression of mRNA genes. 419 The 16S rRNA gene serves as the reference. For A, B and E, error bars indicate the mean \pm standard deviation of 420 at least three biological replicates. Statistical significance was calculated using a two-tailed Student's $t$-test. *, $p$ $421<0.05 ; * * * *, p<0.0001$. DL, detection limit.

422 Figure 4. Effects of cations and temperature on killing by other effectors. A, Survival of $E$. coli after 423 competition with $V$. cholerae TseL-active mutant $t s e L^{+}$on LB source-1-agar or source-2-agar plates. B, Effect of 424 EDTA-treatment on survival of $E$. coli competed with $V$. cholerae $t \mathrm{seL}^{+}$. The $\mathrm{ddH}_{2} \mathrm{O}$-treated agar plates serve as 425 with $V$. cholerae strains at $30^{\circ} \mathrm{C}$ or $37^{\circ} \mathrm{C}$ (normalized to $4 e f f_{c}$ ), as indicated. For A to D, WT, wild type; 4 eff $c$, the 4-antibacterial-effector-inactive mutant; $t s e L^{+}$, the TseL-active only mutant. vas $X^{+}$, the VasX-active only mutant. $\operatorname{vgrG} 3^{+}$, the VgrG3-active only mutant. Survival of E. coli strains was enumerated by serial plating on selective medium. Survival of killer strains was shown in Supplementary Figure 4A-4D, respectively. E, Toxicity assay of $P$. aeruginosa PAO1 strains ectopically expressing Tat-VasX and its colicin-inactivated mutant Tat-Vas $\mathrm{X}^{\Delta \mathrm{C} 16}$ on plates with gentamycin and irgasan at $30^{\circ} \mathrm{C}$ or $37^{\circ} \mathrm{C}$. For A-E, error bars indicate the mean \pm standard deviation of three biological replicates. Statistical significance was calculated using a two-tailed Student's $t$-test 434 for two groups comparison or one-way ANOVA test for more than two groups comparison. *, $p<0.05 ; * *, p$ 435 $<0.01 ; * * * *, p<0.0001$. DL, detection limit. 
436 Figure 5. Competition analysis of TseH-mediated killing on raw agar. A, Survival of E. coli prey competed 437 with $V$. cholerae strains on LB raw agar plates, as indicated. B, Survival of the $V$. cholerae $\Delta t$ tsiH mutant as prey. 438 For $\mathbf{A}$ and $\mathbf{B}$, killer strains are indicated at the bottom. WT, wild type; 4 eff c, the 4-antibacterial-effector-inactive 439 mutant; $\operatorname{seL}^{+}$, the TseL-active only mutant. Survival of prey cells was enumerated by serial plating on selective 440 medium. Killer survival was shown in Supplementary Figure 5A-5B respectively. Error bars indicate the mean $441 \pm$ standard deviation of three biological replicates. Statistical significance was calculated using a two-tailed 442 Student's $t$-test. **, $p<0.01 ; * * * *, p<0.0001$. DL, detection limit.

443 Figure 6. Abiotic factors and stress response dictate the outcome of T6SS-mediated competition. 444 Environmental abiotic factors affect the susceptibility of prey cells to T6SS effectors. These factors include the 445 presence metal cations, temperature, antibiotic molecules. Prey cells that do not possess specific immunity proteins 446 rely on innate immunity-like stress response pathways for protection. As an example, the PhoPQ two-component 447 system was activated under $\mathrm{Mg}^{2+}$-limited environment, which is important for protecting E. coli from TseH448 mediated toxicity. Temperature and other environmental factors likely also modulate prey cell physiology to alter 449 cell sensitivity to T6SS-mediated competition. These abiotic factors thus play a key role in the dynamic 450 competition of a T6SS-related microbial community. 
bioRxiv preprint doi: https://doi.org/10.1101/2021.05.27.445954; this version posted May 27, 2021. The copyright holder for this preprint (which was not certified by peer review) is the author/funder. All rights reserved. No reuse allowed without permission.

Figure 1

A

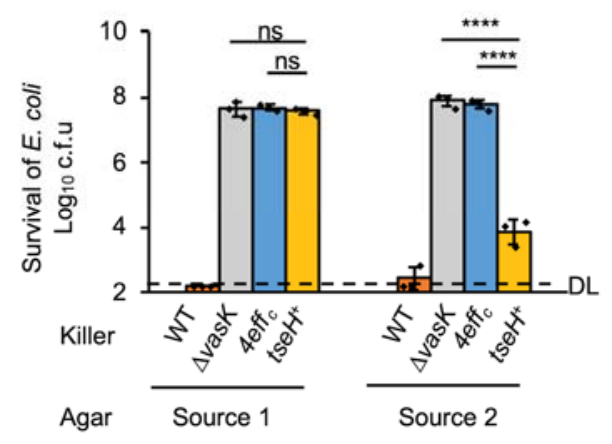

C

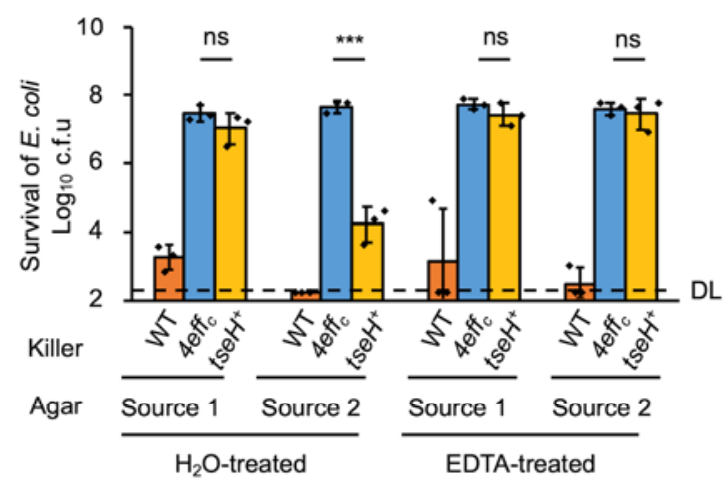

B

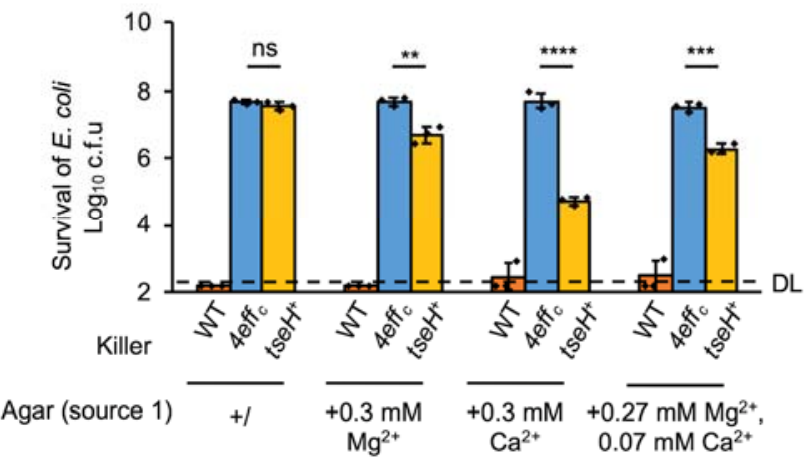

D

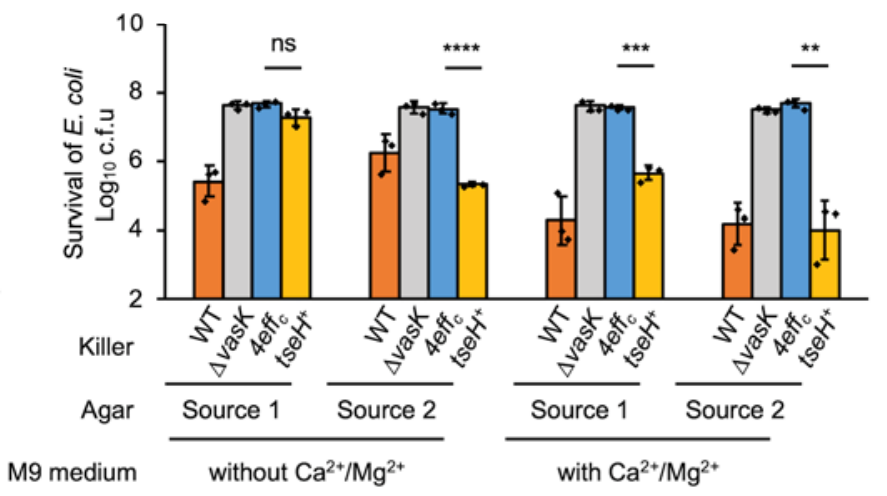

E

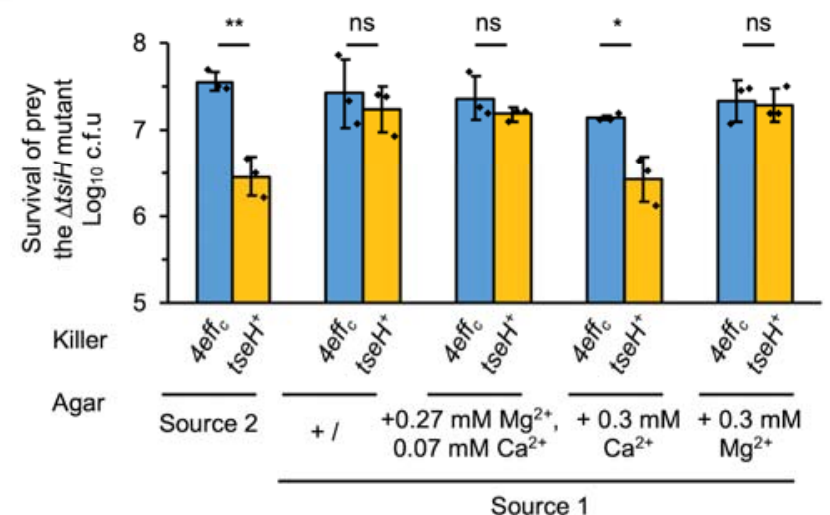

Source 1 
bioRxiv preprint doi: https://doi.org/10.1101/2021.05.27.445954; this version posted May 27, 2021. The copyright holder for this preprint (which was not certified by peer review) is the author/funder. All rights reserved. No reuse allowed without permission.

Figure 2

A

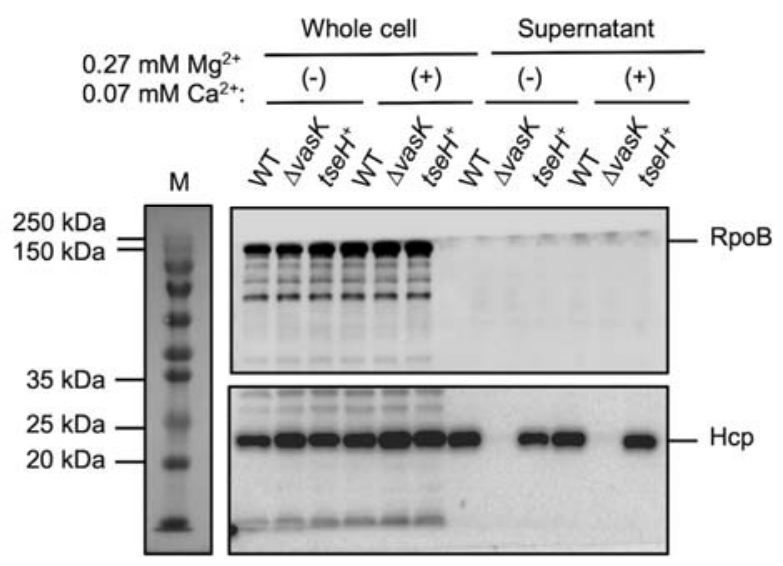

B

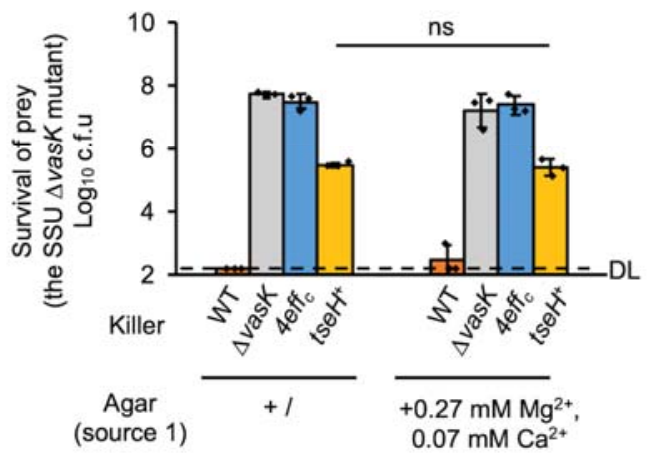


bioRxiv preprint doi: https://doi.org/10.1101/2021.05.27.445954; this version posted May 27, 2021. The copyright holder for this preprint (which was not certified by peer review) is the author/funder. All rights reserved. No reuse allowed without permission.

Figure 3

A

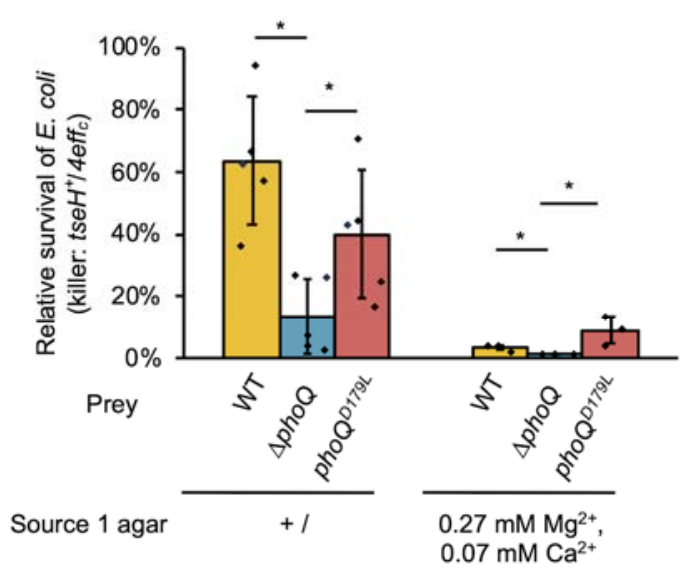

C

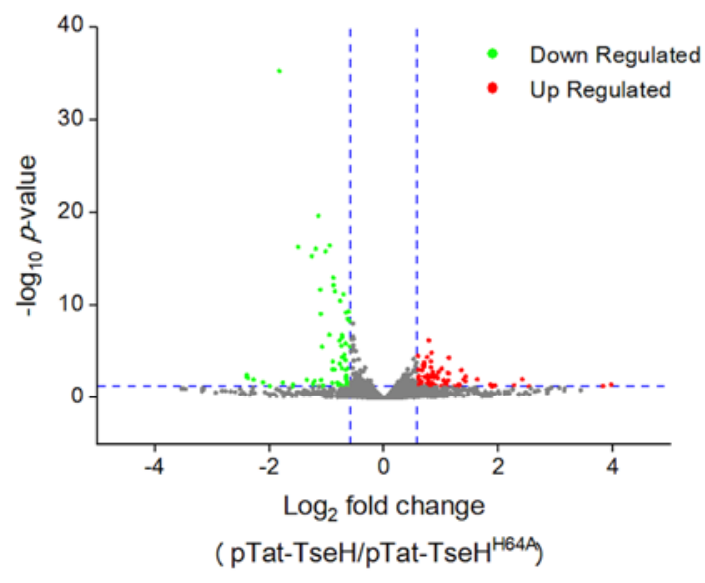

B

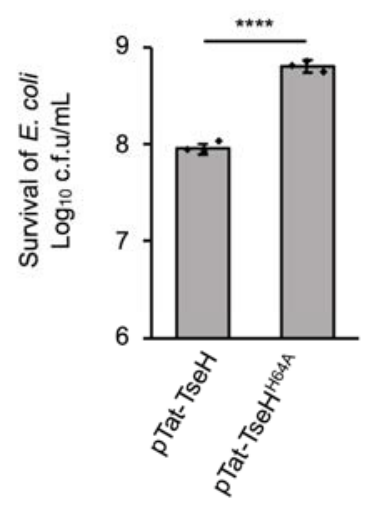

D

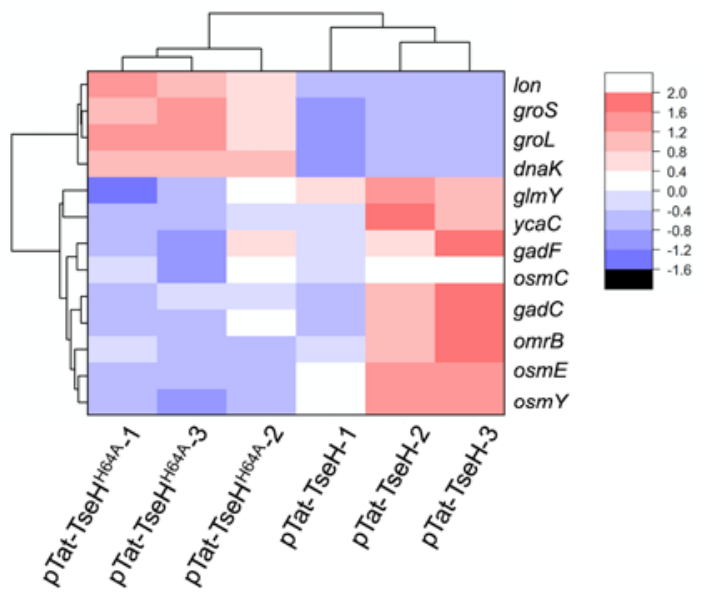

E

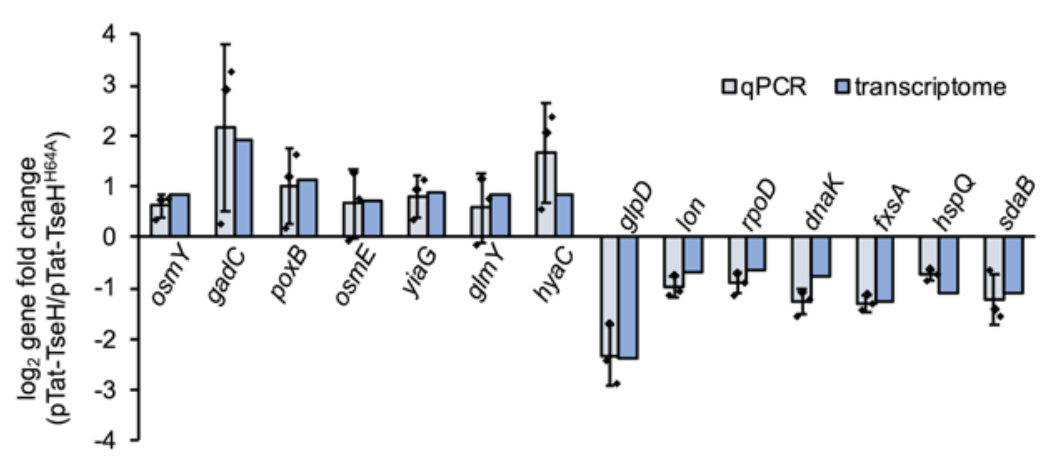


bioRxiv preprint doi: https://doi.org/10.1101/2021.05.27.445954; this version posted May 27, 2021. The copyright holder for this preprint (which was not certified by peer review) is the author/funder. All rights reserved. No reuse allowed without permission.

Figure 4

A

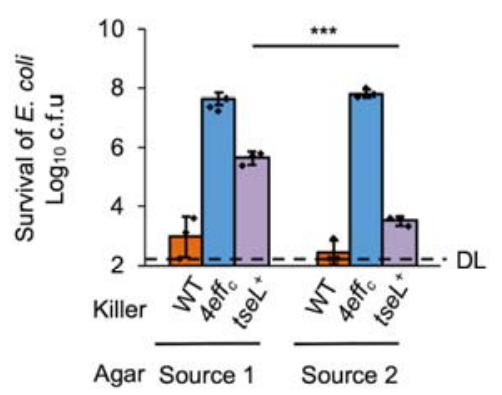

B

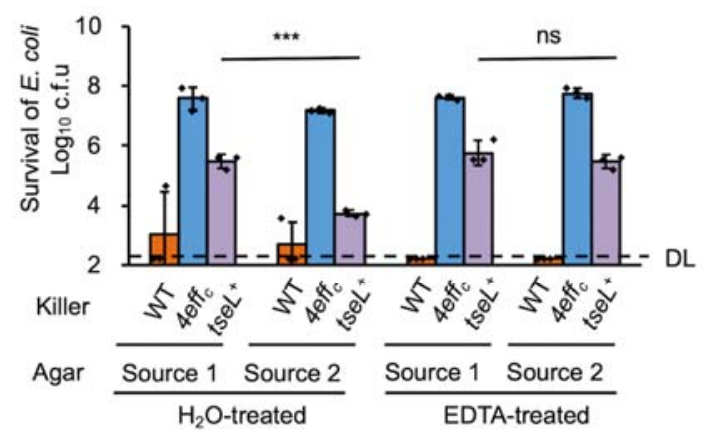

C

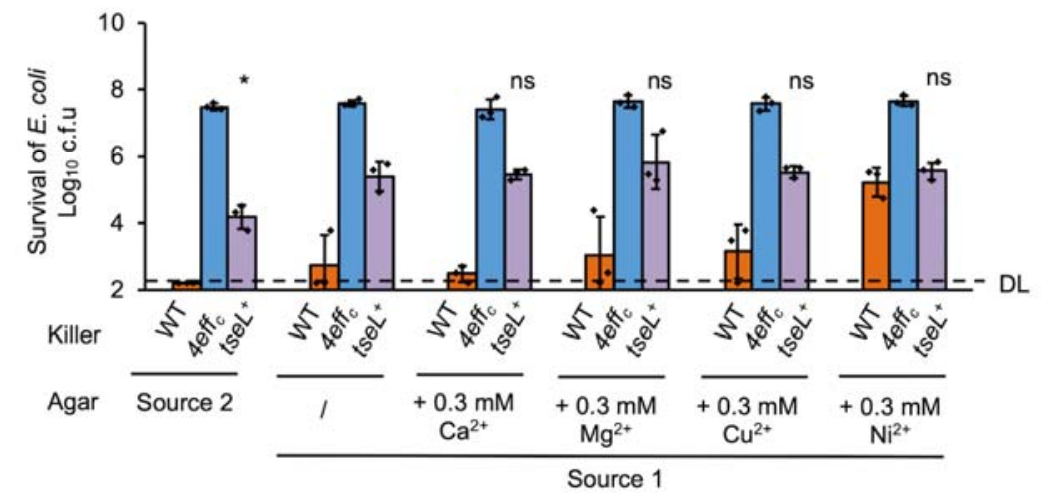

D

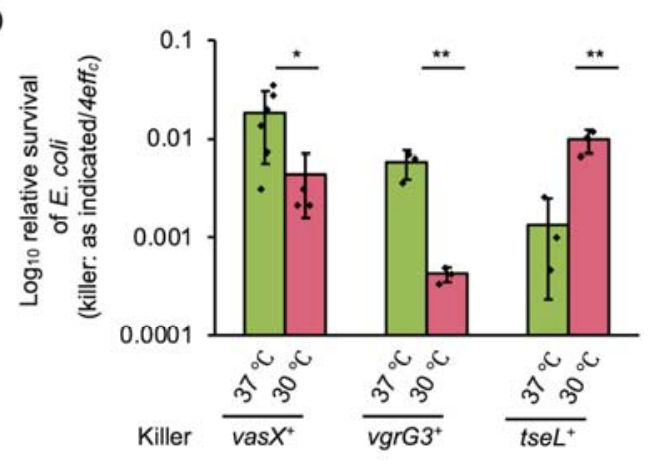

E

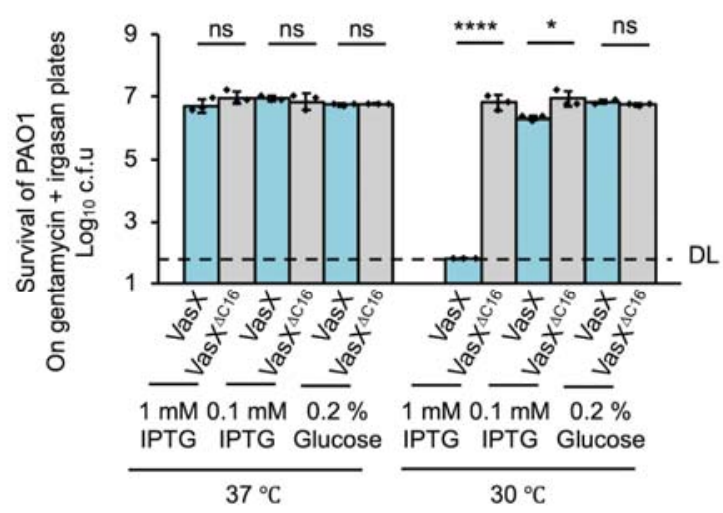


bioRxiv preprint doi: https://doi.org/10.1101/2021.05.27.445954; this version posted May 27, 2021. The copyright holder for this preprint (which

Figure 5

A

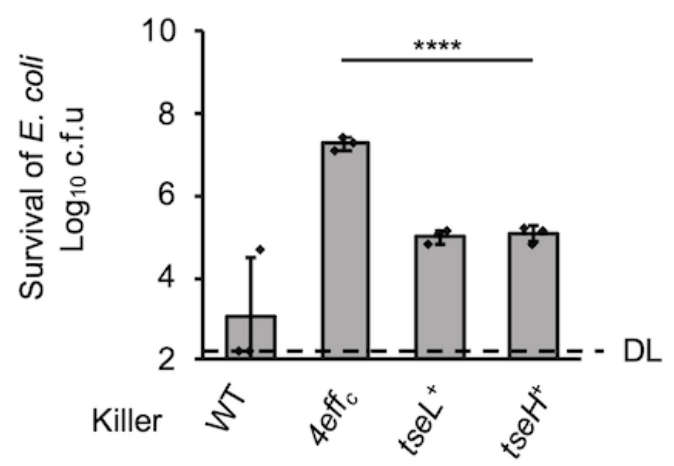

B

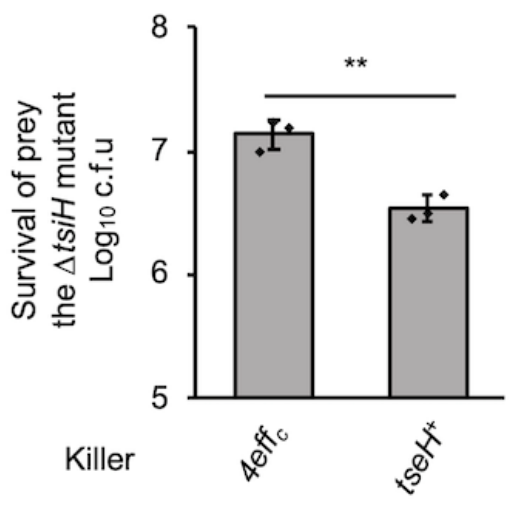


Figure 6

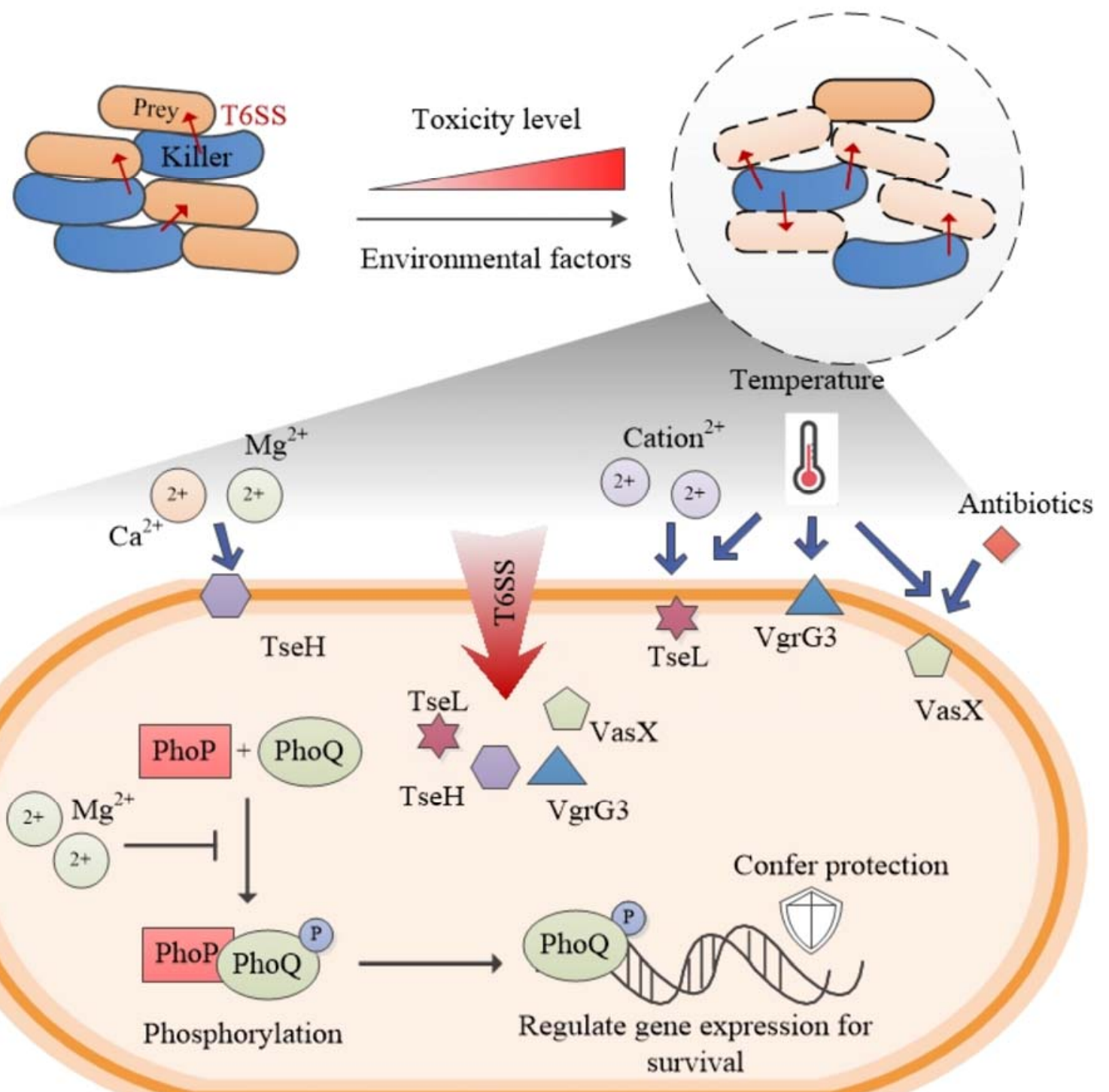

